\title{
Totipotency in the mouse
}

\author{
Guangming $\mathrm{Wu}^{1} \cdot$ Lei Lei $^{1,2} \cdot$ Hans R. Schöler ${ }^{1,3}$
}

Received: 31 October 2016 / Revised: 20 December 2016 / Accepted: 12 January 2017 /Published online: 19 January 2017

(C) The Author(s) 2017. This article is published with open access at Springerlink.com

\begin{abstract}
In mammals, the unicellular zygote starts the process of embryogenesis and differentiates into all types of somatic cells, including both fetal and extraembryonic lineages - in a highly organized manner to eventually give rise to an entire multicellular organism comprising more than 200 different tissue types. This feature is referred to as totipotency. Upon fertilization, oocyte maternal factors epigenetically reprogram the genomes of the terminally differentiated oocyte and spermatozoon and turn the zygote into a totipotent cell. Today, we still do not fully understand the molecular properties of totipotency. In this review, we discuss recent findings on the molecular signature and mechanism of transcriptional regulation networks in the totipotent mouse embryo.
\end{abstract}

Keywords Totipotency $\cdot$ Zygote $\cdot$ Transcription factors

\section{Introduction}

Multicellular organisms typically originate from a single totipotent cell, the zygote. In plants, structurally and functionally specialized cells of leaves, roots, stem, floral parts, and endosperm retain the potential to revert back to the undifferentiated

Hans R. Schöler

office@mpi-muenster.mpg.de

1 Department of Cell and Developmental Biology, Max Planck Institute for Molecular Biomedicine, Röntgenstrasse 20, 48149 Münster, Germany

2 Department of Histology and Embryology, Harbin Medical University, 194 Xuefu Road, Nangang District, Harbin 150081, China

3 Medical Faculty, University of Münster, Domagkstr. 3, 48149 Münster, Germany state and form entire new plants, irrespective of their ploidy level (haploid, diploid, or triploid). The potential of terminally differentiated cells to regenerate whole plants was referred to as "cellular totipotency" by the remarkable German plant physiologist Göttlieb Haberlandt in his famous address to the German Academy in 1902 [1]. Now, regeneration of totipotency from isolated single plant cells is well demonstrated [2]. However, in the mouse, totipotency seems to be restricted up to two-cell embryos. The term "Totipotency" is defined by two related but different criteria: (1) the ability of a single cell to contribute to all cell lineages, including the TE, of an organism; and (2) more stringently, the ability of a single cell to develop into a complete organism [3, 4]. The zygote is the ultimate totipotent cell (Fig. 1). Blastomeres from two-cellstage embryos also fulfill the more stringent definition for totipotency [5-7]. Prior to the first lineage segregation, totipotency is lost gradually [8]. Some blastomeres from eight-cell-stage embryos contribute to the development of all lineages in chimeric mice [9-11], and thus provide evidence for totipotency based on the less stringent definition. In this review, we discuss present-day understanding of the transcription factor networks and epigenetic reprogramming involved in the emergence of totipotency in the mammalian embryo.

\section{Establishment of totipotency}

\section{Zygotic genome activation}

Following fertilization, maternal factors play a leading role in epigenetically resetting the parental DNA and histones across the genome of the zygote, thereby preparing for whole-genome activation and establishment of 


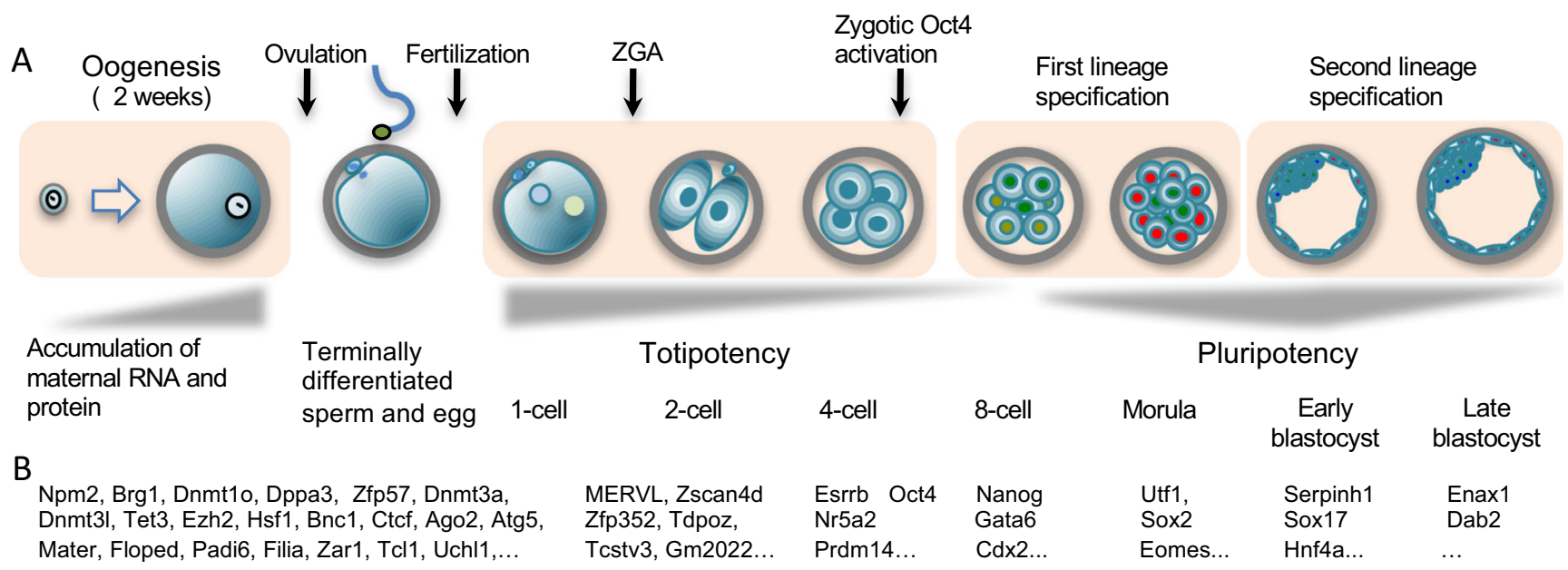

Gene transcription

Fig. 1 Mouse preimplantation development. a Mature oocytes are ovulated from the ovary into the oviduct and fertilized by sperm to establish totipotent zygotes that divide and become blastocysts, and finally implant in the uterus at embryonic day 4.5. b After fertilization,

totipotency. A burst of transcription-known as zygotic genome activation (ZGA)-begins at the late one-cell stage and peaks at the two-cell stage in the mouse [12]. ZGA is characterized by more efficient use of TATA-less promoters [13]; activation of repetitive elements [14], particularly endogenous retrotransposons, e.g., murine endogenous retrovirus with a leucine tRNA primer binding site (MERVL) at the two-cell stage as a marker for totipotent cells [15]; uncoupling of transcription and translation in zygotes [16]; and activation of enhancers for transcription in two-cell embryos [17]. ZGA provides the first step in the establishment of totipotency.

\section{Maternal factor storage}

During oogenesis, the volume of oocytes dramatically increases to accommodate the storage of maternal factors (RNA, proteins) required for establishing totipotency and ZGA, such as nucleoplasmin (NPM) 2 [18], and the subcortical maternal complex (SCMC, including Mater, Tle6, Floped, Padi6, Filia) [19]. In the growing oocytes, subcortical ribonucleoprotein (RNP) particle domains (SCRDs) are formed to serve as the storage compartment of maternal messenger RNA (mRNA) [20]. Maternally accumulated yes-associated protein (YAP) has recently been identified to play a critical role in ZGA [21]. However, the paucity of biological materials from mouse oocytes and zygotes has hampered our effort to understand how maternal factors reprogram cells to totipotency [22]. Further identification of key maternal regulators and their functions could greatly facilitate studies for improving chromatin reprogramming $[23,24]$.

\section{Histone modifications}

Hyperaccessibility of chromatin by transcriptional machinery is a prerequisite for ZGA. Chromatin accessibility is largely determined by histone modifications of its N-terminal tails ("marks"), which acts as a fundamental epigenetic regulator to control the gene expression during embryo development in mammals.

There are two major types of histone modifications involved in regulation of gene expression during the ZGA: lysine acetylation and lysine (tri)methylation. H4 acetylation makes pronucleus permissive for active transcription [25]. Loss of the maternal Brg1, a component of the ATP-dependent chromatin remodeling SWI/SNF complex, results in reduced levels of $30 \%$ of zygotic genes and arrest at two-cell, demonstrating that chromatin remodelers that induce to acetylation are required for mouse embryogenesis [26].

The opposing marks histone H3 lysine 4 trimethylation (H3K4me3) and histone H3 lysine 27 trimethylation (H3K27me3) at gene promoter regions are associations with active and repressed genes, respectively. Following fertilization, $\mathrm{H} 3 \mathrm{~K} 4 \mathrm{me} 3$ and $\mathrm{H} 4$ acetylation in the paternal genome are responsible for a minor ZGA. They are depleted in late zygotes stage but reestablished on promoter regions during the major ZGA at the late two-cell stage [27, 28]. On the maternal genome, a noncanonical (nc) form of $\mathrm{H} 3 \mathrm{~K} 4 \mathrm{me} 3$ (ncH3K4me3) is present broadly in oocytes and zygote and overlaps almost exclusively with partially methylated DNA domains. The ncH3 4 me 3 is erased in the late two-cell embryos [27]. Active removal of broad H3K4me3 domains by the lysine demethylases KDM5A and 
KDM5B is required for ZGA and is essential for early embryo development [29].

\section{Protamine-to-histone replacement}

At the time of fertilization, the chromatin molecules of the paternal and maternal genomes exhibit different epigenetic marks and organization. The paternal genome is haploid, and most of it is packaged densely, with protamines rather than histones, while the maternal genome is diploid, as it arrests at metaphase II, and is packaged with histones. After a sperm penetrates the cytoplasm of the oocyte, the paternal genome decondenses, enabling protamine removal and repackaging with the stored maternal histones in the absence of DNA replication, while the maternal genome completes meiosis. These newly integrated histones possess a transcriptionally permissive pattern of modifications, including $\mathrm{H} 4$ hyperacetylation [25] and $\mathrm{H} 3 \mathrm{~K} 9$ and H3K27 monomethylation [30]. Of note, when round spermatids, which contain DNA that is still associated with histones, are injected into oocytes by round spermatid injection (ROSI), paternal genome failed to undergo active DNA demethylation, but when mature sperm, which contain DNA associated mainly with protamines, are injected into oocytes by intracytoplasmic sperm injection (ICSI), active paternal genome demethylation is observed [31]. These results indicate that the protamine-histone exchange may cause the pronounced demethylation of the paternal DNA in the zygote. However, as both ROSI- and ICSIderived embryos have the same likelihood of developing to term, paternal genome demethylation mediated by protamine-histone exchange is not an essential step in ZGA and establishment of totipotency [32].

\section{Histone variant H3.3}

During preimplantation development, striking changes in epigenetic modifications in the form of deposition of histone variants, reestablishment of histone marks, and DNA demethylation occur throughout the genome.

Both canonical histones $(\mathrm{H} 2 \mathrm{~A}, \mathrm{H} 2 \mathrm{~B}, \mathrm{H} 3$, and $\mathrm{H} 4)$ and variant histones (which have sequence homology and structural similarity with canonical histones, but harbor specialized functions and play essential roles in chromatin reprogramming) are incorporated into chromatin throughout the first cell cycle of the zygote. Variant histones preferentially are deposited into specific genomic regions to form nucleosomes with unique biophysical characteristics. As one of the three variants of histone $\mathrm{H} 3$ in mammals, H3.3 differs from canonical H3 in only four amino acids and incorporates into chromatin in both a replication-independent and a replication-coupled manner. H3.3 interacts with the chaperones HIRA and Daxx/ATRX and is enriched in transcriptionally active regions [24]. H3.3 also localizes to telomeres, where its presence depends upon ATRX [33]. Following fertilization in the mouse, maternal H3.3 is deposited by HIRA onto paternal chromatin during the protamine-to-histone exchange [34], an essential step for oocyte-mediated reprogramming [35]. H3.3 is also required for maintaining chromatin in the decondensed state in early mouse embryos by antagonizing linker $\mathrm{H} 1$, an activity dependent on H3.3 lysine 36 [36].

\section{Active DNA demethylation}

The genome-wide cytosine methylation profile differs among cell types, and it functions as a form of memory of the cell's identity [37]. 5-methylcytosine $(5 \mathrm{mC})$ is present mostly in CpG sequences [37-39]. Methylation occurs globally in mammalian genomes at various loci including genes, transposons, repeat sequences, and intergenic DNA [40]. The enzymes that methylate cytosine to form $5 \mathrm{mC}$ have been well characterized. DNA methyltransferase (DNMT) 1 preferentially methylates hemi-methylated cytosines in $\mathrm{CpG}$ sequences and thus acts as a methyltransferase that maintains genome-wide methylation patterns during replication [41-43]. DNMT3A and DNMT3B can methylate unmethylated $\mathrm{CpG}$ sequences and hence function as de novo methyltransferases [44]. DNMT3L has no catalytic activity but recruits DNMT3A and DNMT3B to their target sequences by recognizing nucleosomes that carry unmethylated histone H3 lysine 4 (H3K4) [45-49].

In concordance with histone acquisition, the paternal genome undergoes genome-wide loss of DNA methylation via an active mechanism prior to the start of DNA replication [50, 51].

Recent studies have found a new mechanism of active demethylation involving prior modification of methylated cytosine and nucleotide excision and repair. 5-hydroxymethylcytosine $(5 \mathrm{hmC})$, a stable hydroxylated metabolite of $5 \mathrm{mC}$, was first identified in the genome of T-even bacteriophages [52], and it is produced as an oxidation damage product of $5 \mathrm{mC}[53,54]$. Subsequent studies have found this to actually be a physiologically relevant DNA modification in mammals, e.g., in mouse neurons and embryonic stem cells (ESCs) $[55,56]$. The hydroxylation of $5 \mathrm{mC}$ into $5 \mathrm{hmC}$ is catalyzed by a family of dioxygenases - the ten-eleven translocation (TET) $1 / 2 / 3$ proteins. TET proteins convert $5 \mathrm{mC}$ into $5 \mathrm{hmC}[56]$, and further into 5-formylcytosine $(5 \mathrm{fC})$ and 5 carboxymethylcytosine $(5 \mathrm{caC})$ for excision $[57,58]$. As $5 \mathrm{hmC}$ has a significantly lower affinity for methyl-CpG binding proteins [59], it may be directly involved in epigenetic regulation. Indeed, genome-wide DNA demethylation in the zygote is accompanied by Tet3-driven genome-wide oxidation of $5 \mathrm{mC}$ into $5 \mathrm{hmC}$ [60-62]. Such $5 \mathrm{hmC}$ formation does not account for the initial loss of paternal $5 \mathrm{mC}$ in the early pronuclear stage, but it is dependent on the activity of zygotic 
Dnmt3a and Dnmt1, suggesting that Tet3 is targeting de novo methylated sites for the accumulation of $5 \mathrm{hmC}$ [63].

Although recent sequence data has shown active demethylation in maternal DNA as well $[64,65]$, high levels of $5 \mathrm{hmC}$ are detected only in the paternal genome of the zygote $[60$, 66]. A maternal knockout of Tet 3 has been shown to prevent both elevation of $5 \mathrm{hmC}$ and reduction of $5 \mathrm{mC}$ levels in the paternal genome, impair promoter demethylation of Oct4 (Pou5f1) and Nanog, delay the activation of a paternally derived Oct 4 transgene, and cause frequent death of the resulting embryos [62]. These findings suggest that during normal development, TET3 converts $5 \mathrm{mC}$ into $5 \mathrm{hmC}$ in the paternal genome, and that TET3-mediated hydroxylation of $5 \mathrm{mC}$ accounts for at least some of the active DNA demethylation of the paternal genome. The ubiquitin ligase Cullin-ring finger ligase-4 (CRL4) has recently been reported to induce TET3 activity and plays an essential role in female fecundity [67], further strengthening the importance of active DNA demethylation during embryonic development.

\section{Activation of embryonic Oct4 expression}

The maternal octamer-binding transcription factor 4 (Oct4), encoded by the gene Pou5fl hereafter referred to as Oct4, is at the top of the pluripotency regulatory hierarchy in pluripotent cells $[62,63]$. However, several recent studies using conditional genetic depletion of maternal Oct 4 have found that the oocytes of Oct $4^{\text {floxfflox }} / \mathrm{ZP} 3^{\text {Cre/t }}$ female mice are capable of completing full-term development after fertilization, indicating that Oct4 is not required for initiating totipotency or pluripotency in embryos [68-70]. The two cell-like ESCs are found to lose Oct4 expression at the protein level [15], suggesting that Oct4 activation in early embryos demarcates pluripotency and totipotency. Still, Oct4 is at the top of the pluripotency regulatory hierarchy in pluripotent cells [71, 72]. It forms a positive feedback loop [73] and is essential for maintaining pluripotency [74]. Therefore, identifying upstream factors of Oct 4 activation in early embryos is critical for understanding the molecular regulation network of totipotency and transition from totipotency to pluripotency. There are a few transcriptional factors found to be involved in the regulation of Oct4 expression. In proliferating stem cells, Promyelocytic leukemia $(\mathrm{Pml})$ protein, along with the transcription factors TR2, SF1, and Sp1, and the Brg1dependent chromatin remodeling complex (BRGC), associates with the Oct4 promoter to maintain a nucleosome-free region for Oct4 gene expression [75]. Cancer-associated factor Tpt1 has been reported to activate the transcription of Oct4 and Nanog in transplanted somatic nuclei in Xenopus oocytes [76], but knockdown of Tpt1 by small interfering RNA (siRNA) does not reduce Oct4 expression in mouse embryos [68]. The maternal transcription factor spalt-like transcription factor 4 (Sall4) binds to the Oct4 distal enhancer (DE), and evidence shows that injection of Sall4 siRNA into zygotes knocking down Sall4 mRNA levels by $50 \%$ leads to a $70 \%$ reduction of Oct4 expression levels, suggesting that Sall4 is a transcriptional activator of Oct4 expression [77]. Contradictorily, knockdown of Sall4 by injection of more efficient Sall4 siRNA into maternal Oct4-deficient zygotes- to avoid any possible effect of maternal Oct4 as a positive autoregulator - does not lead to any Oct4 expression changes at the blastocyst stage [68]. The nuclear receptor subfamily 5 , group A, member $2(\mathrm{Nr} 5 \mathrm{a} 2)$, also known as liver receptor homolog-1 (LRH-1), was found to maintain Oct4 expression at the epiblast stage of embryonic development, by binding to the proximal enhancer (PE) and proximal promoter (PP) regions of Oct4, but to play no evident role in the self-renewal of ESCs [78]. However, Nr5a2 can induce epiblast stem cells into ground-state pluripotency - a basal proliferative state that is free of epigenetic restriction [79], and to replace Oct4 in the reprogramming of somatic cells into pluripotent cells [80]. As a component of an active DNA demethylase, activationinduced cytidine deaminase (AID) has also been shown to be required for Oct4 activation during reprogramming [81]. A genome-scale RNA interference (RNAi) screen in ESCs has identified components of the Pol II-associated factor 1 (Pafl) complex that have strong effects on Oct4 expression, and shown that PaflC overexpression blocks the differentiation of ESCs while PaflC knockdown causes expression changes similar to those caused by Oct4 or Nanog depletion [82]. Studies in search for oocyte master genes have revealed a novel oocyte-specific eukaryotic translation initiation factor 4E (Eif4eloo) [83] and a large number of oocyte-specific genes with yet unknown functions, such as those belonging to the homeodomain transcription factor Obox family [84]. To this day, it is unclear how Oct4 expression is activated in the embryo.

\section{Molecular signature of totipotency}

Unlike the case for pluripotency, the mechanism underlying the molecular regulation of totipotency remains largely unknown. In mice, only the zygote and two-cell-stage blastomeres can generate an entire organism on their own, and are therefore regarded as totipotent cells [6]. The morphology of two-cell embryos is characterized by lack of 4,6-diamidino-2phenylindole (DAPI)-stained chromocenters in the nucleus [85], and the high chromatin mobility at the two-cell stage progressively decreases with development [86]. The transcriptional profile of two-cell embryos is characterized by activation of major satellites, MERVL, and two-cell-specific genes, such as Eifla-like genes (which include Gm5662, Gm2022, Gm4027, BB287469, Gm2016, Gm21319, Gm8300, and Gm10264), Zscan4 genes (Zscan4b-Zscan4f), Zfp352, and Tdpoz genes (Tdpoz1-Tdpoz5) [87]. A recent study has 
demonstrated that depletion of either the p150 or p60 subunit of chromatin assembly factor-1 (CAF-1) in ESCs leads to the formation of 2-cell-like cells with a morphology and transcriptional profile similar to those of two-cell-stage embryos [88]. As CAF-1 performs the first step of the chromatin assembly process by bringing $\mathrm{H} 3$ and $\mathrm{H} 4$ in close proximity to the daughter DNA strands [89] and as the absence of functional CAF-1 delays nucleosome assembly [90], the inefficiency of chromatin assembly in two-cell embryos has been proposed to be a key mechanism in establishing totipotency [88].

Retrotransposon transcripts contribute a significant portion to the transcriptome during ZGA. Retrotransposons can also act as alternative promoters in the activation of protein-coding genes by generating chimeric transcripts with retrotransposon gene junctions [14]. The most active LINE-1 retrotransposons form a stimulatory auto-enhancing loop, indicating that maternal retrotransposon transcripts could activate endogenous retrotransposons after fertilization [91].

Zscan4 is activated during ZGA [92] and can act as an activator of spontaneous telomere sister chromatid exchange (T-SCE) and telomere elongation in mouse ESCs [93]. Knockdown of Zscan 4 by siRNAs delays progression from the two-cell to four-cell stage, and thus leads to the formation of blastocysts that fail to implant or proliferate in blastocyst outgrowth culture [92]. Zscan4 is essential for generation of induced pluripotent stem cells (iPSCs), and its ectopic expression can activate early embryonic genes and improve the efficiency of iPSC generation [94]. Expression of the Zscan4 gene family plays important roles in genome stability and maintenance of telomeres [93]. Of note, the absence of nuclear receptor subfamily 0 , group $\mathrm{B}$, member 1 (Nr0b1), also known as Dax1, which is an important component of the transcription factor network that governs pluripotency in mouse ESCs, also leads to the overexpression of two-cell embryo-specific transcripts, including Zscan $4 \mathrm{c}$, preventing normal self-renewal by inducing arrest at the G2 phase followed by cell death [95].

Furthermore, another recent study has described a small transient ESC/iPSC population with fluctuating expression of a particular retrotransposon, MERVL and a transcriptome that closely resembles that observed in the blastomeres of the totipotent, two-cell embryos [15], indicating that some features of totipotent cells can be regained occasionally in pluripotent cells. This phenomenon provides us with a novel way of studying certain aspects of totipotency. However, the study did not prove these two-cell like cells to be totipotent according to the stringent criteria, in which a single totipotent cell can develop into a complete organism. Moreover, nearcomplete $(95 \%-99 \%)$ knockdown of muERV-L transcripts by three different siRNA duplexes did not interfere with full-term embryonic development (unpublished data), suggesting that the transcripts of retrotransposon elements are not involved in the regulation of totipotency, but rather occur as a consequence of global DNA demethylation prior to ZGA.

Recent progress in identifying two-cell marker genes and new players in the genome-wide demethylation process has shed light on the molecular mechanism governing totipotency. Nevertheless, many questions still remain unanswered. To date, no totipotent cell lines have been established in vitro. The upstream "master" signals that trigger the establishment of totipotency have not yet been identified. Given the distinct phases of ZGA in the mouse, it is likely that multiple regulators/cofactors are associated with regulators of ZGA to ensure temporal gene activation for establishing totipotency. It would be interesting to see how the upstream signals relate to histone replacement or modification, genome-wide DNA demethylation, ZGA, and the expression of two-cell-specific genes, particularly those of maternal origin. The identification of two-cell marker genes has moved us closer to solving the fundamental question in developmental biology of how totipotency is established.

Acknowledgements Open Access funding provided by Max Planck Society. This work was supported by the Max Planck Society, DFG grants DFG SI 1695/1-2 (SPP1356) and SCHO 340/7-1, and grant NIH R01HD059946-01 from the Eunice Kennedy Shriver National Institute of Child Health and Human Development. We thank Areti Malapetsas for the final editing.

Open Access This article is distributed under the terms of the Creative Commons Attribution 4.0 International License (http:// creativecommons.org/licenses/by/4.0/), which permits unrestricted use, distribution, and reproduction in any medium, provided you give appropriate credit to the original author(s) and the source, provide a link to the Creative Commons license, and indicate if changes were made.

\section{References}

1. Haberland G (1902) Kultureversuche mit isolierten Pflanzenzellen. Sitzungsber Kaiserl Akad Wiss Wien, Math-Naturwiss Cl, Abt J 111:69-92

2. Vasil IK, Vasil V (1972) Totipotency and embryogenesis in plant cell and tissue cultures. In Vitro 8:117-127

3. Ishiuchi T, Torres-Padilla ME (2013) Towards an understanding of the regulatory mechanisms of totipotency. Curr Opin Genet Dev 23: $512-518$

4. Edwards RG, Beard HK (1997) Oocyte polarity and cell determination in early mammalian embryos. Mol Hum Reprod 3:863-905

5. Papaioannou VE, Mkandawire J, Biggers JD (1989) Development and phenotypic variability of genetically identical half mouse embryos. Development 106:817-827

6. Tarkowski AK (1959) Experiments on the development of isolated blastomeres of mouse eggs. Nature 184:1286-1287

7. Tsunoda Y, McLaren A (1983) Effect of various procedures on the viability of mouse embryos containing half the normal number of blastomeres. J Reprod Fertil 69:315-322

8. Tarkowski AK, Suwinska A, Czolowska R, Ozdzenski W (2010) Individual blastomeres of 16- and 32-cell mouse embryos are able to develop into foetuses and mice. Dev Biol 348:190-198 
9. Balakier H, Pedersen RA (1982) Allocation of cells to inner cell mass and trophectoderm lineages in preimplantation mouse embryos. Dev Biol 90:352-362

10. Kelly SJ (1977) Studies of the developmental potential of 4- and 8cell stage mouse blastomeres. J Exp Zool 200:365-376

11. Rossant J (1976) Postimplantation development of blastomeres isolated from 4- and 8-cell mouse eggs. J Embryol Exp Morphol 36: 283-290

12. Schultz RM (1993) Regulation of zygotic gene activation in the mouse. BioEssays 15:531-538

13. Davis W Jr, Schultz RM (2000) Developmental change in TATAbox utilization during preimplantation mouse development. Dev Biol 218:275-283

14. Peaston AE, Evsikov AV, Graber JH, de Vries WN, Holbrook AE, Solter D, Knowles BB (2004) Retrotransposons regulate host genes in mouse oocytes and preimplantation embryos. Dev Cell 7:597-606

15. Macfarlan TS, Gifford WD, Driscoll S, Lettieri K, Rowe HM, Bonanomi D, Firth A, Singer O, Trono D, Pfaff SL (2012) Embryonic stem cell potency fluctuates with endogenous retrovirus activity. Nature 487:57-63

16. Nothias JY, Miranda M, DePamphilis ML (1996) Uncoupling of transcription and translation during zygotic gene activation in the mouse. EMBO J 15:5715-5725

17. Wiekowski M, Miranda M, DePamphilis ML (1991) Regulation of gene expression in preimplantation mouse embryos: effects of the zygotic clock and the first mitosis on promoter and enhancer activities. Dev Biol 147:403-414

18. Burns KH, Viveiros MM, Ren Y, Wang P, DeMayo FJ, Frail DE, Eppig JJ, Matzuk MM (2003) Roles of NPM2 in chromatin and nucleolar organization in oocytes and embryos. Science 300:633-636

19. Li L, Baibakov B, Dean J (2008) A subcortical maternal complex essential for preimplantation mouse embryogenesis. Dev Cell 15: 416-425

20. Flemr M, Ma J, Schultz RM, Svoboda P (2010) P-body loss is concomitant with formation of a messenger RNA storage domain in mouse oocytes. Biol Reprod 82:1008-1017

21. Yu C, Ji SY, Dang YJ, Sha QQ, Yuan YF, Zhou JJ, Yan LY, Qiao J, Tang F, Fan HY (2016) Oocyte-expressed yes-associated protein is a key activator of the early zygotic genome in mouse. Cell Res 26: 275-287

22. Wang S, Kou Z, Jing Z, Zhang Y, Guo X, Dong M, Wilmut I, Gao S (2010) Proteome of mouse oocytes at different developmental stages. Proc Natl Acad Sci U S A 107:17639-17644

23. Gonzalez-Munoz E, Arboleda-Estudillo Y, Otu HH, Cibelli JB (2014) Cell reprogramming. Histone chaperone ASF1A is required for maintenance of pluripotency and cellular reprogramming. Science 345:822-825

24. Shinagawa T, Takagi T, Tsukamoto D, Tomaru C, Huynh LM, Sivaraman P, Kumarevel T, Inoue K, Nakato R, Katou Y et al (2014) Histone variants enriched in oocytes enhance reprogramming to induced pluripotent stem cells. Cell Stem Cell $14: 217-227$

25. Adenot PG, Mercier Y, Renard JP, Thompson EM (1997) Differential $\mathrm{H} 4$ acetylation of paternal and maternal chromatin precedes DNA replication and differential transcriptional activity in pronuclei of 1-cell mouse embryos. Development 124:4615-4625

26. Bultman SJ, Gebuhr TC, Pan H, Svoboda P, Schultz RM, Magnuson T (2006) Maternal BRG1 regulates zygotic genome activation in the mouse. Genes Dev 20:1744-1754

27. Zhang B, Zheng H, Huang B, Li W, Xiang Y, Peng X, Ming J, Wu X, Zhang Y, Xu Q et al (2016) Allelic reprogramming of the histone modification $\mathrm{H} 3 \mathrm{~K} 4 \mathrm{me} 3$ in early mammalian development. Nature 537:553-557
28. Liu X, Wang C, Liu W, Li J, Li C, Kou X, Chen J, Zhao Y, Gao H, Wang $\mathrm{H}$ et al (2016) Distinct features of H3K4me3 and $\mathrm{H} 3 \mathrm{~K} 27 \mathrm{me} 3$ chromatin domains in pre-implantation embryos. Nature 537:558-562

29. Dahl JA, Jung I, Aanes H, Greggains GD, Manaf A, Lerdrup M, Li G, Kuan S, Li B, Lee AY et al (2016) Broad histone H3K4me3 domains in mouse oocytes modulate maternal-to-zygotic transition. Nature 537:548-552

30. Santos F, Peters AH, Otte AP, Reik W, Dean W (2005) Dynamic chromatin modifications characterise the first cell cycle in mouse embryos. Dev Biol 280:225-236

31. Kurotaki YK, Hatanaka Y, Kamimura S, Oikawa M, Inoue H, Ogonuki N, Inoue K, Ogura A (2015) Impaired active DNA demethylation in zygotes generated by round spermatid injection. Hum Reprod 30:1178-1187

32. Polanski Z, Motosugi N, Tsurumi C, Hiiragi T, Hoffmann S (2008) Hypomethylation of paternal DNA in the late mouse zygote is not essential for development. Int J Dev Biol 52:295-298

33. Goldberg AD, Banaszynski LA, Noh KM, Lewis PW, Elsaesser SJ, Stadler S, Dewell S, Law M, Guo X, Li X et al (2010) Distinct factors control histone variant $\mathrm{H} 3.3$ localization at specific genomic regions. Cell 140:678-691

34. Lin CJ, Koh FM, Wong P, Conti M, Ramalho-Santos M (2014) Hira-mediated H3.3 incorporation is required for DNA replication and ribosomal RNA transcription in the mouse zygote. Dev Cell 30: 268-279

35. Wen D, Banaszynski LA, Liu Y, Geng F, Noh KM, Xiang J, Elemento O, Rosenwaks Z, Allis CD, Rafii S (2014) Histone variant H3.3 is an essential maternal factor for oocyte reprogramming. Proc Natl Acad Sci U S A 111:7325-7330

36. Lin CJ, Conti M, Ramalho-Santos M (2013) Histone variant H3.3 maintains a decondensed chromatin state essential for mouse preimplantation development. Development 140:3624-3634

37. Lister R, Pelizzola M, Dowen RH, Hawkins RD, Hon G, TontiFilippini J, Nery JR, Lee L, Ye Z, Ngo QM et al (2009) Human DNA methylomes at base resolution show widespread epigenomic differences. Nature 462:315-322

38. Ramsahoye BH, Biniszkiewicz D, Lyko F, Clark V, Bird AP, Jaenisch R (2000) Non-CpG methylation is prevalent in embryonic stem cells and may be mediated by DNA methyltransferase $3 \mathrm{a}$. Proc Natl Acad Sci U S A 97:5237-5242

39. Tomizawa S, Kobayashi H, Watanabe T, Andrews S, Hata K, Kelsey G, Sasaki H (2011) Dynamic stage-specific changes in imprinted differentially methylated regions during early mammalian development and prevalence of non-CpG methylation in oocytes. Development 138:811-820

40. Suzuki MM, Bird A (2008) DNA methylation landscapes: provocative insights from epigenomics. Nat Rev Genet 9:465-476

41. Bestor T, Laudano A, Mattaliano R, Ingram V (1988) Cloning and sequencing of a cDNA encoding DNA methyltransferase of mouse cells. The carboxyl-terminal domain of the mammalian enzymes is related to bacterial restriction methyltransferases. J Mol Biol 203: 971-983

42. Bestor TH (1992) Activation of mammalian DNA methyltransferase by cleavage of a $\mathrm{Zn}$ binding regulatory domain. EMBO J 11: 2611-2617

43. Li E, Bestor TH, Jaenisch R (1992) Targeted mutation of the DNA methyltransferase gene results in embryonic lethality. Cell 69:915-926

44. Okano M, Xie S, Li E (1998) Cloning and characterization of a family of novel mammalian DNA (cytosine-5) methyltransferases. Nat Genet 19:219-220

45. Aapola U, Kawasaki K, Scott HS, Ollila J, Vihinen M, Heino M, Shintani A, Kawasaki K, Minoshima S, Krohn K et al (2000) Isolation and initial characterization of a novel zinc finger gene, 
DNMT3L, on 21q22.3, related to the cytosine-5-methyltransferase 3 gene family. Genomics 65:293-298

46. Bourc'his D, Bestor TH (2004) Meiotic catastrophe and retrotransposon reactivation in male germ cells lacking Dnmt3L. Nature 431:96-99

47. Bourc'his D, Xu GL, Lin CS, Bollman B, Bestor TH (2001) Dnmt3L and the establishment of maternal genomic imprints. Science 294:2536-2539

48. Hata K, Okano M, Lei H, Li E (2002) Dnmt3L cooperates with the Dnmt3 family of de novo DNA methyltransferases to establish maternal imprints in mice. Development 129:1983-1993

49. Ooi SK, Qiu C, Bernstein E, Li K, Jia D, Yang Z, ErdjumentBromage H, Tempst P, Lin SP, Allis CD et al (2007) DNMT3L connects unmethylated lysine 4 of histone $\mathrm{H} 3$ to de novo methylation of DNA. Nature 448:714-717

50. Mayer W, Niveleau A, Walter J, Fundele R, Haaf T (2000) Demethylation of the zygotic paternal genome. Nature 403: 501-502

51. Oswald J, Engemann S, Lane N, Mayer W, Olek A, Fundele R, Dean W, Reik W, Walter J (2000) Active demethylation of the paternal genome in the mouse zygote. Curr Biol 10:475-478

52. Wyatt GR, Cohen SS (1953) The bases of the nucleic acids of some bacterial and animal viruses: the occurrence of 5hydroxymethylcytosine. Biochem J 55:774-782

53. Burdzy A, Noyes KT, Valinluck V, Sowers LC (2002) Synthesis of stable-isotope enriched 5-methylpyrimidines and their use as probes of base reactivity in DNA. Nucleic Acids Res 30:4068-4074

54. Zuo S, Boorstein RJ, Teebor GW (1995) Oxidative damage to 5methylcytosine in DNA. Nucleic Acids Res 23:3239-3243

55. Kriaucionis S, Heintz N (2009) The nuclear DNA base 5hydroxymethylcytosine is present in Purkinje neurons and the brain. Science 324:929-930

56. Tahiliani M, Koh KP, Shen Y, Pastor WA, Bandukwala H, Brudno Y, Agarwal S, Iyer LM, Liu DR, Aravind L et al (2009) Conversion of 5-methylcytosine to 5-hydroxymethylcytosine in mammalian DNA by MLL partner TET1. Science 324:930-935

57. He YF, Li BZ, Li Z, Liu P, Wang Y, Tang Q, Ding J, Jia Y, Chen Z, $\mathrm{Li} \mathrm{L}$ et al (2011) Tet-mediated formation of 5-carboxylcytosine and its excision by TDG in mammalian DNA. Science 333:1303-1307

58. Ito S, Shen L, Dai Q, Wu SC, Collins LB, Swenberg JA, He C, Zhang Y (2011) Tet proteins can convert 5-methylcytosine to 5formylcytosine and 5-carboxylcytosine. Science 333:1300-1303

59. Valinluck V, Tsai HH, Rogstad DK, Burdzy A, Bird A, Sowers LC (2004) Oxidative damage to methyl-CpG sequences inhibits the binding of the methyl-CpG binding domain (MBD) of methylCpG binding protein 2 (MeCP2). Nucleic Acids Res 32:4100-4108

60. Wossidlo M, Nakamura T, Lepikhov K, Marques CJ, Zakhartchenko V, Boiani M, Arand J, Nakano T, Reik W, Walter $\mathrm{J}$ (2011) 5-Hydroxymethylcytosine in the mammalian zygote is linked with epigenetic reprogramming. Nat Commun 2:241

61. Iqbal K, Jin SG, Pfeifer GP, Szabo PE (2011) Reprogramming of the paternal genome upon fertilization involves genome-wide oxidation of 5-methylcytosine. Proc Natl Acad Sci U S A 108:3642-3647

62. Gu TP, Guo F, Yang H, Wu HP, Xu GF, Liu W, Xie ZG, Shi L, He $\mathrm{X}$, Jin SG et al (2011) The role of Tet3 DNA dioxygenase in epigenetic reprogramming by oocytes. Nature 477:606-610

63. Amouroux R, Nashun B, Shirane K, Nakagawa S, Hill PW, D'Souza Z, Nakayama M, Matsuda M, Turp A, Ndjetehe E et al (2016) De novo DNA methylation drives $5 \mathrm{hmC}$ accumulation in mouse zygotes. Nat Cell Biol 18:225-233

64. Wang L, Zhang J, Duan J, Gao X, Zhu W, Lu X, Yang L, Zhang J, Li G, Ci W et al (2014) Programming and inheritance of parental DNA methylomes in mammals. Cell 157:979-991

65. Guo F, Li X, Liang D, Li T, Zhu P, Guo H, Wu X, Wen L, Gu TP, $\mathrm{Hu} \mathrm{B}$ et al (2014) Active and passive demethylation of male and female pronuclear DNA in the mammalian zygote. Cell Stem Cell $15: 447-458$

66. Iqbal K, Jin S-G, Pfeifer GP, Szabó PE (2011) Reprogramming of the paternal genome upon fertilization involves genome-wide oxidation of 5-methylcytosine. Proc Natl Acad Sci 108:3642-3647

67. Yu C, Zhang YL, Pan WW, Li XM, Wang ZW, Ge ZJ, Zhou JJ, Cang Y, Tong C, Sun QY et al (2013) CRL4 complex regulates mammalian oocyte survival and reprogramming by activation of TET proteins. Science 342:1518-1521

68. Wu G, Han D, Gong Y, Sebastiano V, Gentile L, Singhal N, Adachi K, Fischedick G, Ortmeier C, Sinn M et al (2013) Establishment of totipotency does not depend on Oct4A. Nat Cell Biol 15:1089-1097

69. Frum T, Halbisen MA, Wang C, Amiri H, Robson P, Ralston A (2013) Oct4 cell-autonomously promotes primitive endoderm development in the mouse blastocyst. Dev Cell 25:610-622

70. Le Bin GC, Muñoz-Descalzo S, Kurowski A, Leitch H, Lou X, Mansfield W, Etienne-Dumeau C, Grabole N, Mulas C, Niwa $\mathrm{H}$ et al (2014) Oct4 is required for lineage priming in the developing inner cell mass of the mouse blastocyst. Development 141:1001-1010

71. Chen X, Xu H, Yuan P, Fang F, Huss M, Vega VB, Wong E, Orlov YL, Zhang W, Jiang J et al (2008) Integration of external signaling pathways with the core transcriptional network in embryonic stem cells. Cell 133:1106-1117

72. Rodda DJ, Chew JL, Lim LH, Loh YH, Wang B, Ng HH, Robson P (2005) Transcriptional regulation of nanog by OCT4 and SOX2. J Biol Chem 280:24731-24737

73. Okumura-Nakanishi S, Saito M, Niwa H, Ishikawa F (2005) Oct-3/ 4 and Sox 2 regulate Oct-3/4 gene in embryonic stem cells. J Biol Chem 280:5307-5317

74. Nichols J, Zevnik B, Anastassiadis K, Niwa H, Klewe-Nebenius D, Chambers I, Scholer H, Smith A (1998) Formation of pluripotent stem cells in the mammalian embryo depends on the POU transcription factor Oct4. Cell 95:379-391

75. Chuang YS, Huang WH, Park SW, Persaud SD, Hung CH, Ho PC, Wei LN (2011) Promyelocytic leukemia protein in retinoic acidinduced chromatin remodeling of Oct 4 gene promoter. Stem Cells 29:660-669

76. Koziol MJ, Garrett N, Gurdon JB (2007) Tpt1 activates transcription of oct4 and nanog in transplanted somatic nuclei. Curr Biol 17: 801-807

77. Zhang J, Tam WL, Tong GQ, Wu Q, Chan HY, Soh BS, Lou Y, Yang J, Ma Y, Chai L et al (2006) Sall4 modulates embryonic stem cell pluripotency and early embryonic development by the transcriptional regulation of Pou5fl. Nat Cell Biol 8:1114-1123

78. Gu P, Goodwin B, Chung AC, Xu X, Wheeler DA, Price RR, Galardi C, Peng L, Latour AM, Koller BH et al (2005) Orphan nuclear receptor LRH-1 is required to maintain Oct4 expression at the epiblast stage of embryonic development. Mol Cell Biol 25: 3492-3505

79. Guo G, Smith A (2010) A genome-wide screen in EpiSCs identifies $\mathrm{Nr} 5 \mathrm{a}$ nuclear receptors as potent inducers of ground state pluripotency. Development 137:3185-3192

80. Heng JC, Feng B, Han J, Jiang J, Kraus P, Ng JH, Orlov YL, Huss M, Yang L, Lufkin T et al (2010) The nuclear receptor Nr5a2 can replace Oct4 in the reprogramming of murine somatic cells to pluripotent cells. Cell Stem Cell 6:167-174

81. Bhutani N, Brady JJ, Damian M, Sacco A, Corbel SY, Blau HM (2010) Reprogramming towards pluripotency requires AIDdependent DNA demethylation. Nature 463:1042-1047

82. Ding L, Paszkowski-Rogacz M, Nitzsche A, Slabicki MM, Heninger AK, de Vries I, Kittler R, Junqueira M, Shevchenko A, Schulz H et al (2009) A genome-scale RNAi screen for Oct4 modulators defines a role of the Pafl complex for embryonic stem cell identity. Cell Stem Cell 4:403-415 
83. Evsikov AV, Graber JH, Brockman JM, Hampl A, Holbrook AE, Singh P, Eppig JJ, Solter D, Knowles BB (2006) Cracking the egg: molecular dynamics and evolutionary aspects of the transition from the fully grown oocyte to embryo. Genes Dev 20:2713-2727

84. Rajkovic A, Yan C, Yan W, Klysik M, Matzuk MM (2002) Obox, a family of homeobox genes preferentially expressed in germ cells. Genomics 79:711-717

85. Probst AV, Santos F, Reik W, Almouzni G, Dean W (2007) Structural differences in centromeric heterochromatin are spatially reconciled on fertilisation in the mouse zygote. Chromosoma 116: 403-415

86. Boskovic A, Eid A, Pontabry J, Ishiuchi T, Spiegelhalter C, Raghu Ram EV, Meshorer E, Torres-Padilla ME (2014) Higher chromatin mobility supports totipotency and precedes pluripotency in vivo. Genes Dev 28:1042-1047

87. Evsikov AV, de Vries WN, Peaston AE, Radford EE, Fancher KS, Chen FH, Blake JA, Bult CJ, Latham KE, Solter D et al (2004) Systems biology of the 2-cell mouse embryo. Cytogenet Genome Res 105:240-250

88. Ishiuchi T, Enriquez-Gasca R, Mizutani E, Boskovic A, ZieglerBirling C, Rodriguez-Terrones D, Wakayama T, Vaquerizas JM, Torres-Padilla ME (2015) Early embryonic-like cells are induced by downregulating replication-dependent chromatin assembly. Nat Struct Mol Biol 22:662-671
89. Smith S, Stillman B (1991) Stepwise assembly of chromatin during DNA replication in vitro. EMBO J 10:971-980

90. Takami Y, Ono T, Fukagawa T, Shibahara K, Nakayama T (2007) Essential role of chromatin assembly factor-1-mediated rapid nucleosome assembly for DNA replication and cell division in vertebrate cells. Mol Biol Cell 18:129-141

91. Fadloun A, Le Gras S, Jost B, Ziegler-Birling C, Takahashi H, Gorab E, Carninci P, Torres-Padilla ME (2013) Chromatin signatures and retrotransposon profiling in mouse embryos reveal regulation of LINE-1 by RNA. Nat Struct Mol Biol 20:332-338

92. Falco G, Lee SL, Stanghellini I, Bassey UC, Hamatani T, Ko MS (2007) Zscan4: a novel gene expressed exclusively in late 2-cell embryos and embryonic stem cells. Dev Biol 307:539-550

93. Zalzman M, Falco G, Sharova LV, Nishiyama A, Thomas M, Lee SL, Stagg CA, Hoang HG, Yang HT, Indig FE et al (2010) Zscan4 regulates telomere elongation and genomic stability in ES cells. Nature 464:858-863

94. Hirata T, Amano T, Nakatake Y, Amano M, Piao Y, Hoang HG, Ko MS (2012) Zscan4 transiently reactivates early embryonic genes during the generation of induced pluripotent stem cells. Sci Rep 2:208

95. Fujii S, Nishikawa-Torikai S, Futatsugi Y, Toyooka Y, Yamane M, Ohtsuka S, Niwa H (2015) Nr0b1 is a negative regulator of Zscan4c in mouse embryonic stem cells. Sci Rep 5:9146 